\title{
Toolbox
}

Editor's Note: Toolboxes are intended to describe and evaluate methods that are becoming widely relevant to the neuroscience community or to provide a critical analysis of established techniques. For more information, see http://www.jneurosci.org/misc/ ifa_minireviews.dtl.

\section{Transfection Techniques for Neuronal Cells}

\author{
Daniela Karra ${ }^{1}$ and Ralf Dahm ${ }^{2,3}$ \\ ${ }^{1}$ Institute for Neuropathology, Heinrich-Heine-University Düsseldorf, 40225 Düsseldorf, Germany, ${ }^{2}$ Department of Biology, University of Padua, I-35121 \\ Padua, Italy, and ${ }^{3}$ Spanish National Cancer Research Centre (CNIO), E-28029 Madrid, Spain
}

\section{Introduction}

The transfection of nucleic acids into cells is crucial for the study of many aspects of neuronal cell biology. These include investigating gene and protein function by knocking down target proteins via RNA interference (RNAi) or microRNAs, expressing tagged proteins to track their subcellular localization, behavior, and turnover; and expressing mutant versions of proteins to study the functions of specific domains or mimic disease conditions. Moreover, reporter proteins can be used to detect intracellular ion concentrations or levels of gene expression.

Despite efforts to optimize transfection techniques and protocols for neurons, no method has yet been developed that is suitable for all applications. Instead, the various established methods have their own advantages and drawbacks concerning transfection efficiency, expression levels, cell survival, and viability. Other considerations are the ease of use, reproducibility, cost, and applicability to a given experiment. Researchers therefore often face a bewildering roster of possibilities, making it difficult to decide which approach to take.

In this review we provide a brief overview of methods used to transfect mam-

Received Jan. 12, 2010; revised March 17, 2010; accepted March 22, 2010. We thank Drs. Bernhard Götze, Stefanie Hahn, Fabian Tübing, John P. Vessey, Volker Vogel, Manuel Zeitelhofer, and Milena ZeitelhoferAdzemovic for critically reading this manuscript. We apologize to all scientists whose work could not be cited due to space constraints.

Correspondence should be addressed to Ralf Dahm, Department of Biology, University of Padua, Via Ugo Bassi 58/B, I-35121 Padova, Italy. E-mail: ralf.dahm@bio.unipd.it.

DOI:10.1523/JNEUROSCI.0183-10.2010

Copyright $\odot 2010$ the authors $\quad 0270-6474 / 10 / 306171-07 \$ 15.00 / 0$ malian neural precursors and postmitotic neurons either isolated from the developing brain or already established in culture. Like other postmitotic cells, differentiated neurons present a particular challenge regarding the efficiencies for introducing and expressing exogenous constructs. Another important limitation of working with mammalian neurons is that they tend to be very sensitive to physical stress, alterations in temperature, $\mathrm{pH}$ shifts, or changes in osmolarity. It is therefore important to manipulate them as carefully as possible during preparation and the transfection procedure.

Because of limited space, our scope is restricted to the most common methods currently used and to important recent advances. We highlight which techniques are especially suited for a given question or context. In particular, we focus on protocols that yield high transfection efficiencies (as is needed for quantitative or biochemical analyses) or minimally perturb cell physiology (an important consideration for live cell imaging). Summaries of the advantages and drawbacks of the different methods and their suitability for a given experiment are summarized in Table 1.

\section{Electrical transfection methods}

Electroporation temporarily alters the properties of the plasma membrane by exposing cells to a voltage pulse. This allows charged extracellullar material, e.g., plasmids, to enter the cell (Washbourne and McAllister, 2002). Electroporated material mainly enters the cytoplasm. Therefore, the expression rates of transfected plasmids in postmitotic cells, such as neurons, tend to be relatively low with con- ventional electroporation (up to 15-20\%), and high transfection efficiencies are often achieved at the expense of cell survival and viability. Moreover, electroporation generally only works with embryos or dissociated neurons, restricting its use to undifferentiated cells, and there are reports of subsequent developmental abnormalities such as uncharacteristically long neurites. These disadvantages complicate analyses of neuronal differentiation and hamper patch-clamp experiments (DibHajj et al., 2009).

Nucleofection is a modified form of eletroporation, which uses a series of high voltage pulses that enable plasmids to directly enter the nucleus. In addition to cell type-specific transfection programs, nucleofection solutions are used that mimic the physiological microenvironment of the transfected cell type during the procedure. These modifications tend to result in higher transfection rates [e.g., an average of $60-80 \%$ after optimization and up to $95 \%$ for neuronal cells isolated from embryonic day 17 (E17) rat brains], better cell survival than that afforded by conventional electroporation techniques, and normal subsequent differentiation into mature neurons in culture (Zeitelhofer et al., 2007; Zeitelhofer et al., 2009b).

Nucleofection is the method of choice when high transfection efficiencies are essential, such as for quantitative analyses of knock-down efficiencies after RNAi, where untransfected cells would skew the analyses (Zeitelhofer et al., 2007). While short hairpin RNA plasmids tended to be comparatively difficult to nucleofect with high efficiencies, a recent study has achieved 
Table 1. Summary of advantages and disadvantages of different techniques commonly used to transfect mammalian neurons

\begin{tabular}{|c|c|c|c|c|c|c|c|}
\hline & Best suited for & Strengths & Limitations & Toxicity & $\begin{array}{l}\text { Onset, level, and duration } \\
\text { of expression }^{a}\end{array}$ & Maximum insert size & $\begin{array}{l}\text { Genome } \\
\text { integration }\end{array}$ \\
\hline Electroporation & $\begin{array}{l}\text { Cell types/tissues: Neuronal cell lines and } \\
\text { freshly isolated primary neuronal } \\
\text { cells in vitro; whole embryos in vivo } \\
\text { Applications: Transfection of large num- } \\
\text { bers of robust cells in vitro (in sus- } \\
\text { pension) or in vivo when high } \\
\text { transfection efficiencies are required }\end{array}$ & $\begin{array}{l}\text { Simple and quick protocol, relatively } \\
\text { little optimization required }\end{array}$ & $\begin{array}{l}\text { (1) Can only be used for freshly } \\
\text { isolated neurons or cells in } \\
\text { suspension that have yet to } \\
\text { produce neurites; } \\
\text { (2) transfection efficiencies } \\
\text { limited by premature voltage } \\
\text { pulse termination; } \\
\text { (3) relatively expensive equip- } \\
\text { ment and reagents }\end{array}$ & $\begin{array}{l}\text { Variable depending on cell } \\
\text { type and electropora- } \\
\text { tion parameters used } \\
\text { (robust cell types tend } \\
\text { to survive the proce- } \\
\text { dure better) }\end{array}$ & $\begin{array}{l}\text { Typically within hours; expression } \\
\text { levels variable depending on } \\
\text { electroporation parameters } \\
\text { used }\end{array}$ & No limit & No \\
\hline Nucleofection & $\begin{array}{l}\text { Cell types: Neuronal cell lines and freshly } \\
\text { isolated primary neuronal cells in } \\
\text { vitro } \\
\text { Applications: } \\
\text { (1) Quantitative and biochemical } \\
\text { analyses because of very high } \\
\text { transfection efficiencies, e.g., } \\
\text { assessment of protein down- } \\
\text { regulation after RNAi-mediated } \\
\text { knock-down; } \\
\text { (2) introduction of genetic material } \\
\text { into neural progenitor cells with } \\
\text { subsequent expansion and/or } \\
\text { differentiation }\end{array}$ & $\begin{array}{l}\text { (1) Very high transfection efficien- } \\
\text { cies (typically 50\%; up to } \\
95 \% \text { after optimization); } \\
\text { (2) often results in nuclear localiza- } \\
\text { tion of transfected plasmids } \\
\text { yielding higher expression } \\
\text { rates; } \\
\text { (3) reproducible and simple to } \\
\text { perform once the procedure has } \\
\text { been optimized }\end{array}$ & $\begin{array}{l}\text { (1) Can only be used for freshly } \\
\text { isolated neurons or cells in } \\
\text { suspension that have yet to } \\
\text { produce neurites; } \\
\text { (2) relatively expensive equip- } \\
\text { ment and reagents; } \\
\text { (3) can require optimization of } \\
\text { programs and nucleofection } \\
\text { solutions used }\end{array}$ & $\begin{array}{l}\text { Relatively low cell toxicity } \\
\text { because of finely regu- } \\
\text { lated sequences of } \\
\text { voltage pulses and cell } \\
\text { type-specific nucleo- } \\
\text { fection solutions }\end{array}$ & $\begin{array}{l}\text { Typically within hours; moderate } \\
\text { expression rates, therefore } \\
\text { possible to harvest cells up to } \\
\text { several days after transfection } \\
\text { to assess, for example, maxi- } \\
\text { mal downregulation of target } \\
\text { proteins or long-term } \\
\text { phenotypes }\end{array}$ & No limit & No \\
\hline $\begin{array}{l}\text { Single cell electro- } \\
\text { poration }\end{array}$ & $\begin{array}{l}\text { Cell types: Individual neuronal cells in } \\
\text { vitro or in vivo, including mature, } \\
\text { fully differentiated neurons } \\
\text { Applications: } \\
\text { (1) Transfection of neurons in brain } \\
\text { slices and in intact brains of living } \\
\text { animals; } \\
\text { (2) assessment of the morphology, } \\
\text { function, and behavior of single } \\
\text { cells in intact neuronal networks; } \\
\text { (3) electrophysiological recordings } \\
\text { on individual neurons }\end{array}$ & $\begin{array}{l}\text { (1) Surviving neurons are com- } \\
\text { pletely functional; } \\
\text { (2) subsequent transfection of the } \\
\text { same neuron with more than } \\
\text { one construct at different time } \\
\text { points; } \\
\text { (3) neurons up to } 1 \mathrm{~mm} \text { deep into a } \\
\text { tissue can be transfected }\end{array}$ & $\begin{array}{l}\text { (1) Relatively time consuming; } \\
\text { (2) expensive equipment; } \\
\text { (3) relatively difficult to } \\
\text { optimize }\end{array}$ & Moderate cell survival rate & $\begin{array}{l}\text { Typically within hours; near physi- } \\
\text { ological expression levels } \\
\text { possible because physiological } \\
\text { environment is maintained } \\
\text { (depending on promoter } \\
\text { used), therefore possible to } \\
\text { image cells over months }\end{array}$ & No limit & No \\
\hline $\begin{array}{l}\mathrm{Ca}^{2+} \text {-phosphate } \\
\text { co-precipitation }\end{array}$ & $\begin{array}{l}\text { Cell types: Neuronal cell lines; differenti- } \\
\text { ating and mature (fully differenti- } \\
\text { ated) primary neurons in vitro } \\
\text { Applications: } \\
\text { (1) Analyses requiring low numbers } \\
\text { of transfected cells, e.g., live } \\
\text { imaging of individual neurons in } \\
\text { vitro; } \\
\text { (2) analyses depending on healthy } \\
\text { neurons such as the assessment } \\
\text { of developmental/morphological } \\
\text { phenotypes in neurons, e.g. after } \\
\text { siRNAi; } \\
\text { (3) covisualization of RNAs and } \\
\text { proteins }\end{array}$ & $\begin{array}{l}\text { (1) Very cost-effective; } \\
\text { (2) no specialized equipment } \\
\text { required; } \\
\text { (3) comparatively simple to opti- } \\
\text { mize for a variety of plasmids; } \\
\text { (4) gentle method with minimal } \\
\text { stress for the transfected cells } \\
\text { (after optimization); } \\
\text { (5) amount of transfected DNA can } \\
\text { be titrated to vary expression } \\
\text { levels }\end{array}$ & $\begin{array}{l}\text { (1) Low transfection efficiencies } \\
\text { for post-mitotic neurons } \\
\text { (typically } \sim 5-10 \% \text { ), but } \\
\text { can go up to } 30 \% \text { after } \\
\text { optimization; } \\
\text { (2) transfection procedure can } \\
\text { be relatively time consuming } \\
\text { (progress of crystal forma- } \\
\text { tion and deposition on cells } \\
\text { as well as cell viability may } \\
\text { have to be monitored regu- } \\
\text { larly over several hours) }\end{array}$ & $\begin{array}{l}\text { Low (when crystal size and } \\
\text { exposure time are } \\
\text { optimized) }\end{array}$ & $\begin{array}{l}\text { Typically within hours; depending } \\
\text { on promoter and cell type: } \\
\text { physiological expression levels } \\
\text { within the first } 12-18 \mathrm{~h}\end{array}$ & No limit & No \\
\hline Lipofection & $\begin{array}{l}\text { Cell types: Neuronal cell lines; differenti- } \\
\text { ating and mature (fully differenti- } \\
\text { ated) primary neurons in vitro (and in } \\
\text { vivo following injection of transfec- } \\
\text { tion solution) } \\
\text { Applications: } \\
\text { (1) Transfection of a wide range of } \\
\text { constructs and oligonucleotides; } \\
\text { (2) high transfection efficiencies } \\
\text { (with little optimization) for cell } \\
\text { lines; } \\
\text { (3) high efficiencies for RNAi knock- } \\
\text { downs, also in mature neurons }\end{array}$ & $\begin{array}{l}\text { (1) Very simple and fast procedure } \\
\text { with few optimization steps; } \\
\text { (2) suitable for transient and stable } \\
\text { transfections; } \\
\text { (3) high reproducibility; } \\
\text { (4) cost-effective }\end{array}$ & $\begin{array}{l}\text { Relatively low efficiencies for } \\
\text { post-mitotic neurons (typi- } \\
\text { cally } \sim 1-5 \% \text { ), but can go up } \\
\text { to } 30 \% \text { after optimization }\end{array}$ & $\begin{array}{l}\text { Adverse effects on neuro- } \\
\text { nal morphology } \\
\text { and/or viability have } \\
\text { been reported (de- } \\
\text { pending on cell type } \\
\text { and reagent) }\end{array}$ & $\begin{array}{l}\text { Typically within hours; moderate } \\
\text { to nearly physiological expres- } \\
\text { sion depending on promoter } \\
\text { and cell type }\end{array}$ & No limit & No \\
\hline
\end{tabular}


Table 1. Continued

\begin{tabular}{|c|c|c|c|c|c|c|c|}
\hline & Best suited for & Strengths & Limitations & Toxicity & $\begin{array}{l}\text { Onset, level, and duration } \\
\text { of expression }^{a}\end{array}$ & Maximum insert size & $\begin{array}{l}\text { Genome } \\
\text { integration }\end{array}$ \\
\hline Adenoviruses & $\begin{array}{l}\text { Cell types: Cell lines and primary neuro- } \\
\text { nal cells, including mature, fully } \\
\text { differentiated neurons, in vitro; } \\
\text { whole nervous system, including } \\
\text { adult nervous system, in vivo } \\
\text { Applications: } \\
\text { (1) Efficient in vitro and in vivo gene } \\
\text { delivery, including expression of } \\
\text { GOls only in certain brain regions } \\
\text { after localized inoculation with } \\
\text { viral vectors; } \\
\text { (2) transient and inducible expres- } \\
\text { sion possible; } \\
\text { (3) suited for quantitative and bio- } \\
\text { chemical analyses because of } \\
\text { very high transduction } \\
\text { efficiencies }\end{array}$ & $\begin{array}{l}\text { (1) Very high transduction effi- } \\
\text { ciency in dividing and nondivid- } \\
\text { ing mammalian cells; } \\
\text { (2) no risk of insertional mutagene- } \\
\text { sis, as there is no genome inte- } \\
\text { gration }\end{array}$ & $\begin{array}{l}\text { (1) Labor intensive and } \\
\text { expensive; } \\
\text { (2) safety issues (biosafety level } \\
2 \text { laboratory needed); } \\
\text { (3) immune/inflammatory } \\
\text { responses in vivo; } \\
\text { (4) transduction of glia cells } \\
\text { (can be limited with neu- } \\
\text { ron-specific promoters) }\end{array}$ & $\begin{array}{l}\text { High when high virus titers } \\
\text { are used }\end{array}$ & $\begin{array}{l}\text { Onset after a few days; high levels } \\
\text { of expression that can last for } \\
\text { weeks to even months }\end{array}$ & $\begin{array}{c}\sim 7.5 \text { kb (high-capacity, } \\
\text { helper-dependent } \\
\text { AdVs: up to } 34 \mathrm{~kb} \text { ) }\end{array}$ & No \\
\hline $\begin{array}{l}\text { Adeno-associated } \\
\text { viruses }\end{array}$ & $\begin{array}{l}\text { Cell types: Cell lines and primary neuro- } \\
\text { nal cells, including mature, fully } \\
\text { differentiated neurons, in vitro; } \\
\text { whole nervous system, including } \\
\text { adult nervous system, in vivo } \\
\text { Applications: } \\
\text { (1) Efficient in vitro (cell lines, pri- } \\
\text { mary postmitotic neurons) and in } \\
\text { vivo gene delivery; } \\
\text { (2) transient and stable } \\
\text { transduction; } \\
\text { (3) transduction of neurons in brain } \\
\text { slices; } \\
\text { (4) suited for quantitative and bio- } \\
\text { chemical analyses because of } \\
\text { very high transduction } \\
\text { efficiencies; } \\
\text { (5) natural tropisms allow specific } \\
\text { transduction of different cell } \\
\text { types }\end{array}$ & $\begin{array}{l}\text { (1) Very high transduction efficien- } \\
\text { cies in dividing and nondividing } \\
\text { mammalian cells; } \\
\text { (2) naturally replication } \\
\text { incompetent/non-pathogenic; } \\
\text { (3) can integrate into the host } \\
\text { genome }\end{array}$ & $\begin{array}{l}\text { (1) Labor-intensive and } \\
\text { expensive; } \\
\text { (2) safety issues (biosafety level } \\
2 \text { laboratory needed); } \\
\text { (3) can cause immune/inflam- } \\
\text { matory responses in vivo; } \\
\text { (4) no site-specific integration } \\
\text { into the genome with re- } \\
\text { combinant vectors; risk of } \\
\text { insertional mutations }\end{array}$ & Low & $\begin{array}{l}\text { Onset } \sim 2 \text { weeks after transduc- } \\
\text { tion; high levels of expression }\end{array}$ & $\sim 5 \mathrm{~kb}$ & Yes \\
\hline Lentiviral vectors & $\begin{array}{l}\text { Cell types: Cell lines and primary neuro- } \\
\text { nal cells, including mature, fully } \\
\text { differentiated neurons, in vitro; } \\
\text { whole nervous system, including } \\
\text { adult nervous system, in vivo } \\
\text { Applications: } \\
\text { (1) Efficient in vitro (cell lines, pri- } \\
\text { mary postmitotic neurons) and in } \\
\text { vivo gene delivery; } \\
\text { (2) transient and stable transduction } \\
\text { and inducible expression; } \\
\text { (3) transduction of neurons in brain } \\
\text { slices; } \\
\text { (4) suited for quantitative and bio- } \\
\text { chemical analyses because of } \\
\text { very high transduction } \\
\text { efficiencies }\end{array}$ & $\begin{array}{l}\text { (1) Very high transduction efficien- } \\
\text { cies in dividing and nondividing } \\
\text { mammalian cells } \\
\text { (2) easy to produce high-titer } \\
\text { stocks and simple transduction } \\
\text { procedure; no/little purification } \\
\text { of viruses needed; } \\
\text { (3) low cell toxicity; } \\
\text { (4) integration into the genome; } \\
\text { (5) transduction of specific cell } \\
\text { types, possible via pseudotyp- } \\
\text { ing of viral vectors }\end{array}$ & $\begin{array}{l}\text { (1) Labor-intensive and } \\
\text { expensive; } \\
\text { (2) safety issues (biosafety level } \\
2 \text { laboratory needed); } \\
\text { (3) no site specific integration } \\
\text { into the genome; possibility } \\
\text { of insertional mutagenesis }\end{array}$ & Low & $\begin{array}{l}\text { Few hours after transduction; high } \\
\text { levels of expression }\end{array}$ & $\sim 10 \mathrm{~kb}$ & Yes \\
\hline $\begin{array}{l}\text { Herpes simplex } \\
\text { viruses }\end{array}$ & $\begin{array}{l}\text { Cell types: Cell lines and primary neuro- } \\
\text { nal cells, including mature, fully } \\
\text { differentiated neurons, in vitro; } \\
\text { whole nervous system, including } \\
\text { adult nervous system, in vivo } \\
\text { Applications: } \\
\text { (1) Efficient in vitro (cell lines, post- } \\
\text { mitotic primary neurons) and in } \\
\text { vivo gene delivery; } \\
\text { (2) tracing of neuronal pathways } \\
\text { in vivo; } \\
\text { (3) transduction of neurons in brain } \\
\text { slices }\end{array}$ & $\begin{array}{l}\text { (1) Natural neurotropism; } \\
\text { (2) very high transduction efficien- } \\
\text { cies in dividing and nondividing } \\
\text { mammalian cells; } \\
\text { (3) no risk of insertional mutagene- } \\
\text { sis, as there is no genome } \\
\text { integration; } \\
\text { (4) large insert size allows trans- } \\
\text { duction of multiple genes or } \\
\text { genomic regions }\end{array}$ & $\begin{array}{l}\text { (1) Labor-intensive and } \\
\text { expensive; } \\
\text { (2) safety issues (biosafety level } \\
2 \text { laboratory needed); } \\
\text { (3) immune/inflammatory } \\
\text { responses in vivo }\end{array}$ & $\begin{array}{l}\text { High; lower with amplicon } \\
\text { vectors }\end{array}$ & $\begin{array}{l}\text { Few hours after transduction; high } \\
\text { levels of expression, decreases } \\
\text { within the first few weeks }\end{array}$ & $\begin{array}{c}>100 \text { kb possible (with } \\
\text { amplicon vectors) }\end{array}$ & No \\
\hline
\end{tabular}




\begin{tabular}{|c|c|c|c|c|c|c|c|}
\hline & Best suited for & Strengths & Limitations & Toxicity & $\begin{array}{l}\text { Onset, level, and duration } \\
\text { of expression }{ }^{a}\end{array}$ & Maximum insert size & $\begin{array}{l}\text { Genome } \\
\text { integration }\end{array}$ \\
\hline Microinjection & $\begin{array}{l}\text { Cell types: Large and robust neurons } \\
\text { (neuronal cell lines; differentiating } \\
\text { and mature primary neurons) in vitro } \\
\text { Applications: } \\
\text { (1) Analyses requiring low numbers } \\
\text { of transfected cells where specific } \\
\text { cells are targeted, e.g. live imag- } \\
\text { ing of individual neurons in vitro; } \\
\text { (2) introduction of molecules other } \\
\text { than nucleic acids; } \\
\text { (3) injection into a specific subcellu- } \\
\text { lar region/compartment }\end{array}$ & $\begin{array}{l}\text { (1) Possible to inject substances } \\
\text { that cannot be synthesized by a } \\
\text { cell, e.g. labeled RNAs, neutral- } \\
\text { izing antibodies; } \\
\text { (2) transfection of specific cells or } \\
\text { cell types in a mixed cell culture; } \\
\text { (3) possibility to inject into the } \\
\text { nucleus (e.g. normal nuclear } \\
\text { processing of RNAs) }\end{array}$ & $\begin{array}{l}\text { (1) Low transfection rates, lim- } \\
\text { ited by the features of the } \\
\text { cell type (larger and more } \\
\text { robust neurons are easier to } \\
\text { inject and have a higher } \\
\text { chance of surviving); } \\
\text { (2) very time consuming; } \\
\text { (3) relatively expensive } \\
\text { equipment }\end{array}$ & $\begin{array}{l}\text { Poor survival rate because } \\
\text { of physical damage of } \\
\text { neurons during } \\
\text { injection }\end{array}$ & $\begin{array}{l}\text { Expression plasmids: typically } \\
\text { within hours; fluorescent sig- } \\
\text { nal of injected labeled RNAs } \\
\text { very low }\end{array}$ & No limit & No \\
\hline Biolistics & $\begin{array}{l}\text { Cell types: All cell types in entire brains } \\
\text { (in vivo) and tissue slices; cultured } \\
\text { cells in vitro, including neuronal cell } \\
\text { lines as well as differentiating and } \\
\text { mature primary neurons (not suited } \\
\text { for early differentiation stages how- } \\
\text { ever, as cells must be firmly adherent } \\
\text { to substrate so as to not detach after } \\
\text { bombardment with gold particles) } \\
\text { Applications: } \\
\text { (1) Experiments on individual neu- } \\
\text { rons (including mature neurons) } \\
\text { in entire brains and spinal cords; } \\
\text { (2) relatively high transfection rates } \\
\text { in vivo without the need for } \\
\text { special safety measures; } \\
\text { (3) combined with two-photon } \\
\text { microscopy: imaging of cells } \\
\text { deeper inside the tissue; } \\
\text { (4) electrophysiological recordings } \\
\text { on individual cells }\end{array}$ & $\begin{array}{l}\text { (1) Analyses on individual neurons } \\
\text { in normal cellular context; } \\
\text { (2) quick protocol; } \\
\text { (3) neurons deep into a tissue can } \\
\text { be transfected }\end{array}$ & $\begin{array}{l}\text { (1) Relatively expensive equip- } \\
\text { ment and reagents; } \\
\text { (2) Relatively low transfection } \\
\text { efficiencies (typically } \\
\sim 2 \% \text { ); however, recently } \\
\text { improved protocols lead to } \\
\text { higher transfection efficien- } \\
\text { cies of up to 10\% (cultured } \\
\text { neurons) and up to 34\% } \\
\text { (slice cultures); } \\
\text { (3) collateral tissue damage } \\
\text { in vivo }\end{array}$ & $\begin{array}{l}\text { Significant cell damage } \\
\text { caused by high pres- } \\
\text { sure and accelerated } \\
\text { gold particles; recently } \\
\text { developed hand-held } \\
\text { gene gun or use of } \\
\text { "mash" show signifi- } \\
\text { cant improvement }\end{array}$ & $\begin{array}{l}\text { Typically within } 1-2 \mathrm{~d} \text { after bom- } \\
\text { bardment; near-physiological } \\
\text { expression generally persists } \\
\text { for a minimum of } 3-4 \mathrm{~d} \text { in cell } \\
\text { culture, up to } 7 \mathrm{~d} \text { in slices }\end{array}$ & No limit & No \\
\hline
\end{tabular}

In addition to the parameters specific to each method, as described in this table, the onset, level, and duration of expression varies, e.g., with the plasmid and promoter used and the expressed construct, as well as the DNA concentration used.

consistently high rates for a range of such plasmids in primary rat (E17) neuronal cells (Zeitelhofer et al., 2009a).

Recently, neural progenitor cells (NPCs) have been transfected via nucleofection with rates of up to $50-60 \%$ ( $~ 80 \%$ stably transfected cells after antibiotic selection) without compromising their proliferation or differentiation potential (Dieterlen et al., 2009). This is particularly interesting because the differentiation of NPCs into different neural cell types bears the promise of repairing or regenerating the nervous system, and the ability to introduce genetic material may thus have important therapeutic implications. While neurons from postnatal and adult brains can also be electroporated or nucleofected (Knoll et al., 2006), these techniques tend to be more effective with younger neuronal cells.

Another recent modification of electroporation, single-cell electroporation, allows the transfer of expression plasmids into individual cells in vivo (Kitamura et al., 2008). To achieve this, a target neuron-up to $1 \mathrm{~mm}$ deep into the brain tissue-is identified and visualized in the intact brain by two-photon microscopy.
The neuron is subsequently electroporated with a high resistance patch pipette containing the plasmid DNA. Following the electroporation, transfected neurons can be imaged and/or targeted for wholecell patch-clamp recordings. Importantly, such neurons were healthy and displayed normal electrophysiological properties, and stable transgene expression could be observed even months after the electroporation (Judkewitz et al., 2009). Target cells can also be electroporated with different constructs at subsequent time points. This allows the expression of multiple transgenes inside the same cell, which is useful when assessing temporal effects of gene expression during neural differentiation and patterning in vivo. Crucially, this method allows analyses of the functional integration of individual neurons within a network. Single-cell electroporation can thus be used to study the role of genes and individual cells in neural circuits, e.g., their activity, plasticity, and behavioral characteristics.

\section{Chemical transfection methods}

$\mathrm{Ca}^{2+}$-phosphate/DNA coprecipitation

The $\mathrm{Ca}^{2+}$-phosphate/DNA coprecipitation method is one of the best established transfection methods and very commonly used to transfect different types of primary neuronal cells as well as cell lines in vitro (Dahm et al., 2008). It is cost effective, does not require specialized equipment, and very easy to establish. This method can be used to transfect neurons at all stages of differentiation, including those that have already formed a functional neuronal network. The basic principle involves the formation of DNA crystals with the $\mathrm{Ca}^{2+}$ ions in the phosphate buffer that then precipitate onto the cells and are presumably taken up via endocytosis. In proliferating cells, the DNA can subsequently enter the nucleus when the nuclear envelope breaks down during mitosis. In postmitotic cells such as neurons, entry into the nucleus is more difficult and the expression rate consequently reduced. Therefore, the transfection efficiency generally lies between 1 and 5\% and, even after optimization, rarely reaches 30\% (Goetze et al., 2004).

An advantage of the $\mathrm{Ca}^{2+}$-phosphate/ DNA coprecipitation is that the time course and level of protein expression can easily be varied by titrating the DNA concentration via alteration of the amount of 
plasmid used (Dahm et al., 2008). This is an advantage, as rapid and strong expression reduces the period in which the overexpressed protein occurs in (near) physiological levels before potentially leading to overexpression artifacts. Importantly, when optimized, transfection via $\mathrm{Ca}^{2+}$-phosphate/DNA coprecipitation results in good cell viability. These advantages make the $\mathrm{Ca}^{2+}$-phosphate/DNA coprecipitation ideally suited for applications requiring low numbers of transfected cells that show physiologically normal behavior. These include, for example, live imaging experiments focusing on single cells in vitro found within a neuronal network in culture (low numbers of transfected cells in complex neuronal networks are an advantage when dendrites and axons of individual neurons have to be identified) or the evaluation of neuronal phenotypes after RNAi (Dahm et al., 2008). This method can also be applied to study the subcellular localization of proteins and the colocalization of proteins and RNAs in developing and mature neurons.

\section{Lipofection}

Conventional lipid-mediated gene delivery is based on cationic lipid molecules. These form small unilamellar liposomes that interact with negatively charged nucleic acids (NAs) and facilitate the fusion of the lipid:NA complex with the negatively charged plasma membrane. Cationic lipid molecules are often combined with a neutral helper lipid, which mediates the fusion of the liposome with the membrane. Newer generations of lipofection reagents, however, use nonliposomal lipids to form a complex with the NAs. This complex is believed to be endocytosed and released into the cytosol. Nonliposomal lipids have been demonstrated to have high transfection efficiencies in a wide variety of cell types, including primary neuronal cells, such as cerebellar granule neurons (Butcher et al., 2009). Importantly, they often work in the presence of serum, which generally results in improved cell growth and viability and may reduce the cytotoxic effects of the transfection.

Lipofections are technically simple, require no specialized equipment, show high reproducibility and low toxicity, and generally require little optimization (although several reagents may have to be tested to achieve the best results with unconventional cell lines/types). They are suitable for both transient and stable transfections of a variety of cell lines. Transfection efficiencies are usually very high when used with cell lines (up to $85 \%$ ), but can vary considerably between cell types. However, the same lipids, when used to transfect postmitotic neurons, tend to give poorer results (typically $1-5 \%$ ), although maximum values of up to $30 \%$ have been reported for primary neurons (Dalby et al., 2004). These comparatively low transfection efficiencies, while affording near endogenous expression levels (Washbourne and McAllister, 2002), limit the application of lipofection for plasmid-based vectors in postmitotic cells.

For RNAi, cytoplasmic delivery of small interfering RNAs (siRNAs) is sufficient. Lipofection reagents efficiently transfer siRNAs, microRNAs, or other oligonucleotides into postmitotic neurons (with up to $83 \%$ efficiency in primary rat hippocampal neurons) (Tonges et al., 2006). Finally, there is great interest in lipid-based DNA delivery for gene therapy, as this method has a lower risk of causing mutations and immune responses than virus-based delivery (Zhdanov et al., 2002).

\section{Virus-based transfection methods}

Viral vectors have received much attention recently and have become powerful tools for gene delivery in vitro and in vivo. In cultured cells, viruses are primarily used to achieve stable genomic integration and an inducible expression of transgenes. In vivo, viruses are often the only viable option when aiming at efficiently introducing transgenes into specific cell types, as is needed, for instance, in gene therapy. Importantly, the viruses described here can infect postmitotic mature (adult) neurons in vitro and in vivo.

Another substantial advantage of viral gene transfer (transduction), both in vitro and in vivo, is the extremely high efficiency. This is not surprising, since viruses evolved to infect cells and express their genetic material. A second major advantage is that different viruses have distinct tropisms. This can help restricting transgene expression to a subset of cell types, greatly facilitating in vivo studies. Given the diversity of biological characteristics of different viruses (tropism, genome integration, strength, duration of expression, etc.), the choice of viral vector depends on the gene of interest (GOI), the targeted cell type, and the experimental application.

Despite these advantages, viral vectors have important limitations. Although most recombinant viral vectors in use today are replication incompetent and thus comparatively safe to use, they still require biosafety level 2 facilities. Furthermore, despite the commercial availability of complete kits, transduction protocols require preparations of recombinant vectors in packaging cell lines and a subsequent purification of virus particles. Packaging cells express viral gene products necessary for the production of infection-competent virions. While this step is time consuming, it ensures that the modified virus used cannot replicate in the target cells after transduction. In addition, some viruses [adeno-associated viruses (AAVs), modified herpes simplex viruses (HSVs)] require the coinfection of packaging cells with a wild-type helper virus to produce infectious virions. This results in a contamination of the supernatant (from which the infectious virions are purified) with helper viruses, which often cannot be fully eliminated during the preparation of the viral stock (Epstein, 2009) and can have cytotoxic effects (White et al., 2002).

\section{Adenoviruses}

Adenoviruses (AdVs) infect target cells, including postmitotic neurons, with high efficiency and in multiple copies. The first generation of adenoviral vectors is cytotoxic if used at high titers and shows late onset and low levels of expression (Washbourne and McAllister, 2002). Moreover, these vectors (as adeno-associated vectors) can cause significant immune responses when used in vivo (Lowenstein et al., 2007; Buning et al., 2008). Recently, a new generation of adenoviral vectors has been designed to overcome this limitation. The genomes of highcapacity, helper-dependent adenoviruses do not encode any viral proteins and, as a consequence, do not elicit immune responses (Lowenstein et al., 2007).

AdVs do not integrate into the host genome and are therefore suitable for transient expression of GOIs. Since the expression can persist for weeks to months, recombinant AdVs are also often used to generate inducible expression systems in vitro and in vivo. A drawback of AdVs when targeting neurons is their preferential infection of glial cells, which can limit the transductions of slices or tissues.

\section{Adeno-associated viruses}

AAVs have emerged as very powerful tools for gene delivery into neurons. Distinct capsid proteins expressed by different AAV serotypes result in the use of different cell surface receptors for cell entry and thus specific tropisms (Buning et al., 2008). Several of these AAV serotypes have been demonstrated to infect primary neurons with high efficiency and low toxicity (Royo et al., 2008), with AAV-2 being the most commonly used. Wild-type AAVs stably integrate into the human genome in a 
site-specific manner. Recombinant AAVbased vectors, however, integrate rarely and randomly because they lack the viral rep gene (Buning et al., 2008).

Since AAVs are naturally replication incompetent, they require a coinfection with an unrelated, wild-type helper virus (e.g., AdV, HSV) to supply essential gene products for the production of infectious virions. The new generation of recombinant AAVs is "helper-free" (while remaining replication deficient), eliminating the handling of an infectious, wild-type helper virus and simplifying the procedure. Moreover, by removing wild-type virus from the gene delivery procedure, the immune response of target cells is minimized. Limitations of AAVs are the late onset of transgene expression ( $\sim 2$ weeks after infection), which hampers experiments with limited time frames, and a maximum insert size of $\sim 5 \mathrm{~kb}$, restricting their use to smaller transgenes (Washbourne and McAllister, 2002).

\section{Lentiviruses}

In contrast to other retroviruses, lentiviruses [including human immunodeficiency virus (HIV)] are capable of infecting nondividing cells. They insert into the host genome and are thus best suited to generate stable transgenic cell lines. Together with their high transduction efficiencies and low toxicity, this makes lentiviral vectors very useful for the generation of inducible expression or knock-down systems in vitro and in vivo. Since stable integration into the host genome carries the risk of insertional mutations, however, recent developments of nonintegrating lentiviral vectors are promising, especially for in vivo applications (Rahim et al., 2009).

To broaden the potential uses of lentiviruses, recombinant HIV-1 vectors were pseudotyped, i.e., HIV-1 envelope proteins, which naturally recognize CD4 receptors on their target cells, were substituted by proteins from other viruses to alter the tropism of the virions (Cockrell and Kafri, 2007, and references therein). This allows the targeting of a wider spectrum of specific cell types with high efficiencies.

Rrecent developments have also reduced the risk posed by replication-competent lentiviruses as follows: (1) viral packaging elements are provided on individual plasmids that need to be cotransfected into packaging cells to produce virions; and (2) six of HIV-1's nine genes encoding important virulence factors have been eliminated without affecting its gene-transfer ability. Most of the commercially available lentiviral systems are based on these third generation vectors, providing a rela- tively safe and efficient way for transient or stable expression of GOIs or RNAi in dividing and nondividing cells.

\section{Herpes simplex viruses}

HSV-1 was the first virus used for gene delivery into neurons. HSVs are particularly attractive for neuroscience, as they naturally infect neurons with high efficiency and can carry large inserts. Furthermore, the ability of HSVs to be transported and transferred across synapses in a retrograde fashion can be used to trace neuronal pathways (Simonato et al., 2000).

Recombinant HSV-1 and amplicon (plasmid)-based vectors have been developed (Epstein, 2009). Amplicon vectors carry almost no genes of the HSV-1 genome (and are thus nontoxic), but have a transgene capacity of up to $150 \mathrm{~kb}$. This allows for the insertion of multiple copies of a transgene or of large genomic regions, including regulatory elements (Epstein, 2009). However, they require a wild-type helper virus (HSV-1) for replication and packaging. A major drawback is the difficulty of producing high-titer stocks of vector particles free of helper virus (Epstein, 2009), which can lead to cytotoxic effects and/or immune responses. The recent development of helper virus-free systems is therefore promising (Fraefel, 2002).

Despite their widespread preclinical use, vector toxicity remains a concern when working in patients. Another limitation, especially for long-term in vivo approaches, is the reduced recombinant gene expression within a few weeks after gene transfer. Recently specific proteins in the HSV-1 virus particle have been associated with the shut-off of transgene expression (Liu et al., 2009), suggesting ways to improve expression over longer periods of time.

\section{Physical transfection methods \\ Microinjection}

During microinjection, nucleic acids are injected into the cytoplasm or nucleus of cells with fine glass capillaries. While microinjection has been used with mammalian neurons, it is more frequently used in experiments with (larger and more robust) invertebrate neurons. A major disadvantage of this technique is the substantial stress caused by disrupting the plasma membrane during microinjection, which results in very low survival rates for many types of neurons. Importantly, to ensure that the injection did not compromise neuronal integrity, function, and/or subsequent development, appropriate controls have to be included in every microinjection experiment (Zhang and Yu, 2008). Despite these drawbacks, this technique has a substantial advantage: it allows the injection of substances that cannot be synthesized by the cell. For instance, directly labeled RNAs (including microRNAs) can be used to follow their subcellular localization and turnover or their association with specific proteins or other RNAs (Schratt et al., 2006). The injection of molecular beacons, which emit a fluorescence signal only upon binding to their target RNA, is an alternative approach to analyzing gene expression or RNA localization in living cells. In addition to injecting RNAs, microinjection can be used to assess the effect of neutralizing antibodies or toxins. Microinjection also allows targeting defined cells in a mixed cell culture or neuronal network. Finally, unlike with other transfection methods, exogenous material can be injected into specific subcellular regions or compartments.

\section{Biolistics}

Biological ballistics, or biolistics, is based on the injection of DNA-coated gold particles by using a motive force, such as high helium pressure (Lo et al., 1994). It can be applied to transfect cells in cultures, tissue slices, or living organs, thus allowing experiments on individual neurons in the context of an entire brain or spinal cord region. This is of particular importance when trying to assess the influence of the neuronal and glial microenvironment and the three-dimensional integration of a neuron within its natural cellular context, which cannot be mimicked in cultures of dissociated neurons or neuronal cell lines. Neurons transfected by this technique can be imaged and targeted for whole-cell patch-clamp recordings. Moreover, the environmental conditions of the slices can be manipulated following the transfection to simulate pathological conditions, such as hypoxia, to mimic stroke or assess the effects of drug treatments.

Compared with viral transfections, biolistic gene transfer is considerably faster, simpler, and does not require additional safety measures. Similar to electroporation, biolistics provides higher transfection rates than lipofection in slice cultures. Importantly, constructs can be transferred to depths of up to $100 \mu \mathrm{m}$ into a tissue or organ (Murphy and Messer, 2001). The efficiency of biolistics (transfection rate and penetration depth), however, has to be counterbalanced with the damage to cells and tissues caused by the particles (size/degree of particle agglomeration). Finally, biolistics also allows the targeting and in vivo analysis of cell types for which no transgenic 
animals are available, e.g., because of the lack of cell type-specific promoters.

\section{References}

Buning H, Perabo L, Coutelle O, Quadt-Humme S, Hallek M (2008) Recent developments in adeno-associated virus vector technology. J Gene Med 10:717-733.

Butcher AJ, Torrecilla I, Young KW, Kong KC, Mistry SC, Bottrill AR, Tobin AB (2009) $\mathrm{N}$-methyl-D-aspartate receptors mediate the phosphorylation and desensitization of muscarinic receptors in cerebellar granule neurons. J Biol Chem 284:17147-17156.

Cockrell AS, Kafri T (2007) Gene delivery by lentivirus vectors. Mol Biotechnol 36:184204.

Dahm R, Zeitelhofer M, Gotze B, Kiebler MA, Macchi P (2008) Visualizing mRNA localization and local protein translation in neurons. Methods Cell Biol 85:293-327.

Dalby B, Cates S, Harris A, Ohki EC, Tilkins ML, Price PJ, Ciccarone VC (2004) Advanced transfection with Lipofectamine 2000 reagent: primary neurons, siRNA, and high-throughput applications. Methods 33:95-103.

Dib-Hajj SD, Choi JS, Macala LJ, Tyrrell L, Black JA, Cummins TR, Waxman SG (2009) Transfection of rat or mouse neurons by biolistics or electroporation. Nat Protoc 4:1118-1126.

Dieterlen MT, Wegner F, Schwarz SC, Milosevic J, Schneider B, Busch M, Romuss U, Brandt A, Storch A, Schwarz J (2009) Non-viral gene transfer by nucleofection allows stable gene expression in human neural progenitor cells. J Neurosci Methods 178:15-23.

Epstein AL (2009) HSV-1-derived amplicon vectors: recent technological improvements and remaining difficulties-a review. Mem Inst Oswaldo Cruz 104:399-410.

Fraefel C (2002) Gene delivery using helper virus-free HSV-1 amplicon vectors. Curr Protoc Hum Genet Chapter 12:Unit 12.12.

Goetze B, Grunewald B, Baldassa S, Kiebler M (2004) Chemically controlled formation of a DNA/calcium phosphate coprecipitate: appli- cation for transfection of mature hippocampal neurons. J Neurobiol 60:517-525.

Judkewitz B, Rizzi M, Kitamura K, Hausser M (2009) Targeted single-cell electroporation of mammalian neurons in vivo. Nat Protoc 4:862-869.

Kitamura K, Judkewitz B, Kano M, Denk W, Hausser M (2008) Targeted patch-clamp recordings and single-cell electroporation of unlabeled neurons in vivo. Nat Methods 5:61-67.

Knoll B, Kretz O, Fiedler C, Alberti S, Schutz G, Frotscher M, Nordheim A (2006) Serum response factor controls neuronal circuit assembly in the hippocampus. Nat Neurosci 9:195-204.

Liu M, Wang X, Geller AI (2009) Improved long-term expression from helper virus-free HSV-1 vectors packaged using combinations of mutated HSV-1 proteins that include the UL13 protein kinase and specific components of the VP16 transcriptional complex. BMC Mol Biol 10:58.

Lo DC, McAllister AK, Katz LC (1994) Neuronal transfection in brain slices using particlemediated gene transfer. Neuron 13:1263-1268.

Lowenstein PR, Mandel RJ, Xiong WD, Kroeger K, Castro MG (2007) Immune responses to adenovirus and adeno-associated vectors used for gene therapy of brain diseases: the role of immunological synapses in understanding the cell biology of neuroimmune interactions. Curr Gene Ther 7:347-360.

Murphy RC, Messer A (2001) Gene transfer methods for CNS organotypic cultures: a comparison of three nonviral methods. Mol Ther 3:113-121.

Rahim AA, Wong AM, Howe SJ, Buckley SM, Acosta-Saltos AD, Elston KE, Ward NJ, Philpott NJ, Cooper JD, Anderson PN, Waddington SN, Thrasher AJ (2009) Efficient gene delivery to the adult and fetal CNS using pseudotyped nonintegrating lentiviral vectors. Gene Ther 16:509-520.

Royo NC, Vandenberghe LH, Ma JY, Hauspurg A, Yu L, Maronski M, Johnston J, Dichter MA, Wilson JM, Watson DJ (2008) Specific AAV serotypes stably transduce primary hippocam- pal and cortical cultures with high efficiency and low toxicity. Brain Res 1190:15-22.

Schratt GM, Tuebing F, Nigh EA, Kane CG, Sabatini ME, Kiebler M, Greenberg ME (2006) A brain-specific microRNA regulates dendritic spine development. Nature 439:283-289.

Simonato M, Manservigi R, Marconi P, Glorioso J (2000) Gene transfer into neurones for the molecular analysis of behaviour: focus on herpes simplex vectors. Trends Neurosci 23:183190.

Tonges L, Lingor P, Egle R, Dietz GP, Fahr A, Bahr $M$ (2006) Stearylated octaarginine and artificial virus-like particles for transfection of siRNA into primary rat neurons. RNA 12: 1431-1438.

Washbourne P, McAllister AK (2002) Techniques for gene transfer into neurons. Curr Opin Neurobiol 12:566-573.

White BH, Cummins TR, Wolf DH, Waxman SG, Russell DS, Kaczmarek LK (2002) HSV-1 helper virus $5 \mathrm{dll} .2$ suppresses sodium currents in amplicon-transduced neurons. J Neurophysiol 87:2149-2157.

Zeitelhofer M, Vessey JP, Xie Y, Tubing F, Thomas S, Kiebler M, Dahm R (2007) Highefficiency transfection of mammalian neurons via nucleofection. Nat Protoc 2:1692-1704.

Zeitelhofer M, Karra D, Vessey JP, Jaskic E, Macchi P, Thomas S, Riefler J, Kiebler M, Dahm R (2009a) High-efficiency transfection of short hairpin RNAs-encoding plasmids into primary hippocampal neurons. J Neurosci Res 87:289-300.

Zeitelhofer M, Vessey JP, Thomas S, Kiebler M, Dahm R (2009b) Transfection of cultured primary neurons via nucleofection. Curr Protoc Neurosci Chapter 4:Unit 4.32.

Zhang Y, Yu LC (2008) Single-cell microinjection technology in cell biology. Bioessays 30: 606-610.

Zhdanov RI, Kuvichkin VV, Shmyrina AS, Jdanov AR, Tverdislov VA (2002) Role of lipid membrane-nucleic acid interactions, DNAmembrane contacts and metal (II) cations in origination of initial cells and in evolution of prokaryotes to eukaryotes. Bioelectrochemistry 58:41-46. 